New End Markets, Supermarket Expansion, and Shifting Social Standards

John Pickles, Department of Geography, University of North Carolina at Chapel Hill, US Stephanie Barrientos, Global Development Institute, University of Manchester, UK Peter Knorringa, Institute of Social Studies, Erasmus University Rotterdam, Netherlands

\begin{abstract}
In recent years, Northern supermarket chains have internationalized rapidly and Southern supermarket chains have expanded their footprint in emerging markets. As they have done so, questions have arisen about the impact of such supermarkets and the extent of consumer demand for social standards (labour standards and fair trade). While standards have been more (or less) codified in their Northern counterparts over recent decades, it remains an empirical question whether -and if so how - they will take hold in the rapidly expanding markets of the global South. The paper analyses the extent to which social standards are applied by Northern lead firms as well as regional supermarkets operating in the global South. It questions the view that Southern consumers and civil society actors are uninterested in social standards, and suggests a more differentiated and complex process driving their selective application in the global South. Value chain concepts of governance help analyse how lead firms are shifting from regimes of control and coordination towards practices of normalization and convergence. We draw on the notion of multi-polar governance to explore emerging pressures for social standards extended to Southern consumer markets and differential channels for convergence emerging across the global North and South. Three case studies highlight diverse channels of convergence on social standards: (i) led by transnational retailers; (ii) led by standards initiatives; and (iii) linking private with public governance. These illustrate that socially responsible consumption is only one element in more complex multi-polar governance processes that reveal trends towards both divergence and convergence in the drivers of social standards within emerging economies.
\end{abstract}

Keywords: Supermarkets, global value chains, production networks, Southern markets responsible consumers 


\section{New End Markets, Supermarket Expansion, and Shifting Social Standards}

\section{Introduction}

The geographies of global production and trade are increasingly being shaped by and through the structures and practices of coordinated inter-firm networks or supply chains, what Gereffi (1994) referred to as producer- and buyer-driven global value chains (GVCs). With over $70 \%$ of international trade now passing through GVCs (UNCTAD 2013), governance by lead firms over their upper tier suppliers has become a central focus of GVC researchers as they analyse the changing geographies of the global economy as Northern lead firms sourcing from low-cost and often low-wage producers in the global South (Gereffi 2014). While also focusing on lead firms in their own work, global production network (GPN) scholars have questioned this firm-centric focus and its presumption that Northern firms structure global economic relations. They highlight more complex and spatially differentiated networks of power relations and corresponding forms of societal embeddedness (Henderson et. al. 2002; Hess 2004; Coe et al. 2008; Guarin and Knorringa 2014; Mayer and Pickles 2014).

In this process supermarket multiples have played a central role in the expansion of transnational networks, first in the global North and increasingly through the expansion of regional supermarkets within many parts of the global South (Coe 2004; Hamilton et. al. 2011). Since the 1980s, supermarket chains have transformed their global sourcing, logistics and supermarket formats to deliver a wide range of quality goods (food and non-food) at competitive prices around the clock to Northern markets (Coe and Wrigley 2009; Coe 2014). In the past decade, global and regionally-based supermarkets have begun to offer the same services to 
markets within Africa, Asia and Latin America, and in the process are reconfiguring South-South trade patterns in significant ways (Reardon et. al. 2007; Humphrey 2007). The rise of supermarket chains and new middle-class consumer markets in the global South has important implications for the ways in which labour and fair trade standards are being driven into supermarket chains in the global South.

In their essay on the question of standards and Southern consumers, Kaplinsky and Farooki (2010) suggested that the regional expansion of Southern lead firms sourcing in the global South is likely to reduce the demand for social and environmental standards, arguing that Southern consumers will not prioritize these issues in their purchasing behaviour. Mainly because civil society organizations in the South are unlikely to generate equivalent pressures on social issues in production as arose in Northern markets. This is an important empirical question about which information is limited. However, there is emerging evidence that increasing demand for quality products and services in emerging economies is being accompanied by increasing consumer awareness of social and environmental issues (Guarin and Knorringa 2014). For example, a 2013 Li and Fung (2013: 53) report found that: "With increasing wealth and rising consumer sophistication, the consumer market in China is undergoing fundamental changes. Most significant is their abiding interest in trading up - more Chinese consumers are willing to pay a premium for higher quality products and services." And a 2014 Nielson survey of 30,000 respondents found that while $55 \%$ of global consumers are willing to pay a premium for socially and environmentally friendly products, the percentage is higher in emerging economies: AsiaPacific (64\%), Latin America (63\%) and Middle East/Africa (63\%) and lower in Europe (40\%) and North America (42\%) (Nielson 2014). 
These survey results are among the first systematic reports of global consumer preferences for standards, and suggest the need to reconsider the more traditional tropes of emerging economies with lower incomes lacking consumer support for social and environmental standards. However, the data should be treated with caution. The Neilson (2014) survey was undertaken through the internet, biasing the findings towards those with access. Moreover, a number of studies have shown a divergence between attitude (preferences displayed in surveys) and behaviour (actual purchases made) when it comes to consumer reporting on socially and environmentally friendly goods. There is also a lack of clarity as to what counts as socially and environmentally friendly, and interpretations vary by country and over time (Guarin and Knorringa 2014; Brown 2015).

Some have questioned homogeneous conceptualisations of middle-income consumers in analyses of ethical consumption within emerging economies, highlighting the diversity among groups and across geographical locations (McEwen et. al. 2015). Others suggest consumer behaviour by new middle class consumers in developing countries is unlikely to follow the same trajectory as middle class consumers in developed countries, with the tipping point towards discretionary spending being reached earlier (Guarin and Knorringa 2014). Indeed, it is important to recognize that responsible consumption is only one dimension of the rise of social standards in emerging economies, while the expansion of retail value chain governance in them is reconfiguring the ways in which standards operate in the global North and South. 
Analysis of governance by lead firms as a driver of private standards has evolved with the expansion of corporate sourcing practices. Early studies highlighted buyer-led firms as drivers of chains involving captive upper tier suppliers (Gereffi 1994). From the 2000s, analysis shifted to different forms of vertical coordination by lead firms as value chains became more diverse and complex - involving market, modular, relational, captive and hierarchical governance (Gereffi et. al. 2005). More recent work has focused on the normalisation of practices across chain actors, and the role of horizontal coordination through multi-polar governance involving a wider array of actors (Ponte and Sturgeon 2014). These involve complex processes of interaction between firm and non-firm (including public, civil society, international) organisations that influence the dynamics of GPNs (Coe and Yeung 2015). An indication of this process has been the rise of multiple social and environmental labelled products sold by northern supermarkets (Gibbon et. al. 2010).

Here we argue that, as the importance of supermarkets has increased and their sourcing and retail footprints have globalized, there has been a parallel shift in the treatment of social standards from a narrow form of governance of control of captive suppliers towards one that involves increased horizontal coordination among retailers and a wider range of institutional actors and initiatives. One consequence is a move towards convergence on common standards' packages that incorporate social standards involving private and non-GVC actors. However, the drivers of emerging practices of normalization and convergence of social standards are not necessarily the same in the global North and South. In the global North, the development and implementation of social standards were largely driven by civil society advocacy campaigns and corporate risk-avoidance in markets with perceived consumer awareness of social issues 
(Barrientos and Dolan 2006). To what extent these processes have filtered through to supermarkets operating within the global South remains an open question.

This paper contributes to addressing this knowledge gap. It does so in the context of geographical expansion of transnational and regional supermarkets, mapping their increasing role in shaping global value chains (GVCs). We elucidate how Northern and emerging Southern supermarkets are expanding their supply chains and supermarket outlets in emerging markets, and assess the consequences of this geographical expansion for the governance and convergence of social standards within the global South. We draw on research undertaken between 2010 -13 in Europe, South Africa and Kenya to show how parallel processes of supermarket expansion have emerged and influenced the application of social standards across the global North and South. The paper focuses on the growth and spread of overlapping private standards and initiatives in the global South and some of the emerging channels of normalization and convergence that transcend more traditional bifurcated conceptions of standards' demands, governance, and practices between the North and South. Our case studies illustrate three channels of convergence on social standards within GPNs: (i) led by global retailers; (ii) led by social standards initiatives; and (iii) linking social standards and national legislation.

Throughout, 'social standards' refer to private not public forms of governance and national regulation, specifically corporate codes of labour practice, and multi-stakeholder and fair trade initiatives addressing rights and conditions of wage labour and smallholder livelihoods (Barrientos and Dolan 2006). We distinguish 'social standards' from environmental standards (including sustainability and organic labels) which are not examined in this paper, although in 
reality these are often linked and can form part of wider product and process standards packages (Guarin and Knorringa 2014; Gibbon et. al. 2010; Henson and Humphrey 2010). Social standards cover both social compliance subject to varying forms of value chain auditing and certification, as well as product labels (Nadvi and Waltring 2004; O'Rourke 2006; ISEAL 2015).

Section two of the paper examines recent trends in the internationalization of supermarket chains in emerging markets, maps out the expansion of large-scale multiple supermarkets within the global South, and describes the emerging new business architectures being created. Section three develops a conceptual framework extending multi-polar governance to interrogate the resulting normalization and convergence of standards. Section four examines empirical evidence from standards management in selected transnational supermarkets and regional supermarket chains in Africa, relating to corporate codes of labour practice and Fairtrade certification.

Section five considers the implications for multi-polar governance through different channels of convergence of social standards within supermarket retail in the global South and concludes.

\section{Internationalisation of Supermarkets in Emerging Economies}

The expansion of transnational supermarkets operating outside their own countries is a response to relatively fast growth in new end markets with profound effects on the geography of retailing. Whilst in 1980, "only 6 of the largest 20 retailers based in Europe operated stores outside their domestic market, by 2000 all but 1 of the top 20 had internationalized their store network" (Dawson 2003: 189). As Table 1 shows, of the top seven retailers worldwide in 2013, only USfocused Kroger did not have substantial revenues from foreign operations. The largest retailer Walmart, with $\$ 469,162$ million in sales in 2012 operates in 28 countries. The French company 
Carrefour - the second largest transnational retailer in 2012 (and $3^{\text {rd }}$ in 2013 with Costco rising to $2^{\text {nd }}$ (Deloitte 2015) - had net sales of $\$ 113,197$ million in 2011 and operated in 33 countries outside France. The UK-based company Tesco was the third largest global retailer in 2011 ( $5^{\text {th }}$ in 2013) (ibid), operating in 13 countries outside the UK. The size and reach of global multiples is making them increasingly important global players. Estimates of the relevance of global multiples to individual countries are also significant. In 2009, Walmart was estimated China's seventh largest trading partner (ahead of the UK), spending more than $\$ 18$ billion annually on Chinese goods, ${ }^{1}$ and by 2011 sourced $\sim 70 \%$ of its total merchandize from China (Chan 2011: 4). In 2011, Walmart acquired a 51\% shareholding in the South African company Massmart Holdings that had outlets in 14 countries across sub-Saharan Africa, doubling Walmart's presence from 14 to 28 countries and providing an important foothold in Africa.

A major driver of the expansion of supermarket retailing within Africa, Asia and Latin America is their rapid economic growth and changing consumer profiles. Urbanization, rising income levels, greater female employment, a growing middle class and access to social media have fuelled consumption growth in emerging markets (Accenture 2011; Nielson 2014). By 2012, four BRICs countries (Brazil, Russia, India and China) plus Indonesia were among the ten largest grocery markets. By 2016 BRICs are forecast to be four of the top five grocery markets globally, behind only the USA (second) and China. ${ }^{2}$

\footnotetext{
1 'Walmart, the US retailer taking over the world by stealth', The Guardian, 12 January 2010. ${ }^{2}$ Source: http://www.retailtimes.co.uk/china-worlds-largest-grocery-market-tops-us1 tn-latestigd-figures-reveals/
} 
Supermarkets sell a range of branded food, clothing and general merchandise supplied by manufacturers, but increasingly also sell ranges of 'own brand' or 'private labels' which now account for approximately two-fifths of UK and one-fifth of US supermarket sales (Lucas and Felsted 2012). ${ }^{3}$ At the same time, regional and domestic retail chains in Africa, Latin America and Central Europe have expanded. Table 1 also provides information on seven emerging market retailers with a regional presence outside their home country. The top three have been selected as the highest ranking Southern-owned companies: Cencosud is the largest, operating in five countries in Latin America; E-MART took over Walmart's operations in Korea in 2006 and also operates in China; Dairy Farm International operates as a major retailer in 12 countries across Asia including mainland China, Indonesia, Cambodia, Malaysia and Singapore. We also focus on the South African companies Shoprite, Pick n Pay, Spar and Woolworth which are the largest African companies with a presence across sub-Saharan Africa.

In their research on the expansion of food supermarket retailing within developing countries, Reardon et al $(2003 ; 2010)$ argued that in all regions the growth of supermarkets had intensified a shift from local decentralized to regional centralized procurement, with wholesalers being replaced by specialized procurement agents, spot markets being replaced by preferred supplier systems, and the introduction and extension of rigorous private standards. Some have highlighted the unevenness of this process in emerging economies particularly in relation to some products such as fresh produce (Humphrey 2007), but others have argued that despite unevenness, centralised distribution continues to expand (Evers et. al. 2013; Reardon et. al.

\footnotetext{
${ }^{3}$ One leading UK supermarket sells 40,000 product lines, approximately two-thirds food and one-third general merchandise, across its stores and on-line grouped into 92 different product categories, sourced from over 70 countries globally (Supermarket interview A2, UK 2013).
} 
2010). Domestic supermarkets are increasingly placed either in a position of competitive disadvantage by TNC supermarket expansion or are having to follow suit. As advances in global logistics and transport have made possible expanded geographies of sourcing (Coe 2014), sourcing practices have transformed the ways in which food, white goods, apparel and other products are produced, distributed and consumed globally. A process that is advanced in the global North is extending quickly (if unevenly) within the global South.

\section{TABLE 1 HERE}

In transnational supermarket chains an array of private standards (technical, social and environmental) were adopted to reduce the transaction costs of managing product heterogeneity across a globalised supply base. These transcend diverse national and international regulations, provide consumer assurance on safety and quality and help to manage reputational risk among consumers (Dolan and Humphrey 2000; Henson and Humphrey 2010). Social standards have evolved within this process. Leading TNC retailers were early movers in adopting social standards within their supply chains. Civil society campaigns over labour abuse in global value chains led to adoption of company codes of labour practice from the late 1990s onwards as a means of guarding reputational risk. Social standards were often added to their packages of product, process and environmental standards, and compliance became a condition of supply to leading retailers (Nadvi and Waltring 2004; Henson and Humphrey 2010; Gibbon et. al. 2010). Many TNC supermarkets also joined multi-stakeholder initiatives, including Ethical Trading Initiatives in the UK, Norway and Denmark as well as SA8000 and Workers' Rights Consortium in the USA. Since the 1990s an increasing number of TNC supermarkets also sell Fairtrade 
certified and related social and environment labelled products (Raynolds and Wilkinson 2007; Reed et. al. 2012; Barrientos and Dolan 2006). This contributed to a proliferation of labels and codes. Gibbon et. al. (2010) cite one estimate of 400 different standards, but are guarded on the extent of proliferation. Nevertheless they cite many examples, including 16 flower and five coffee standards, in addition to individual company standards and codes (branded and own brand) sold by supermarkets.

All the emerging market retailers identified in Table 1 have some form of corporate social and/or environmental responsibility statement on their websites, although the extent to which these are actually applied across their supply chains is unclear (especially in regard to their labour standards). In order to investigate this further, we first consider the analytical drivers of the governance of social standards in retail GVCs, and then turn to different channels through which social standards are being applied by TNC supermarkets operating in emerging economies and by regional supermarkets within Africa.

\section{Governance in Transnational Supermarket Chains}

The rise of transnational supermarkets as lead firms has had an important effect on how we understand the forms and roles of governance within GVCs. The initial focus on the changing role of lead firms as drivers of manufacturer and later buyer-led chains has been complemented in recent years with a growing focus on the relative roles of lead-firm coordination across complex sourcing networks and analysis of normalisation practices to ensure quality control and standardization in the face of enhanced global and regional reputational and market risk (Gereffi et. al. 2005; Gibbon et. al. 2008). In this regard, Gibbon et al (2008) have argued that three 
different governance imperatives underlay different stages of GVC expansion. From the 1980s, GVC analysis focused on the ways in which lead-firms (such as Walmart) were emerging by establishing supply chains structures and forms of economic governance in which lead-firms drive the chains and the actions of captive suppliers in the chain (Gereffi 1994). From the 2000s, increased reputational risk attendant on the creation of complex global supply chain structures resulted in the need for enhanced levels and forms of coordination within value chains. Private standards increasingly formed an important aspect across different forms of vertical governance (Gereffi et al 2005). More recently, the growing need to manage risk (particularly among publicly traded stock companies) with the intensification of competition and on-going squeeze on product prices has encouraged a global shift in value chain operations. A combination of speed, quality, sustainability and cost is now tightly articulated in ways that require not only careful control measures and extensive investments in coordination, but also inter- and intra-firm efforts to normalize actor behaviour so that all actors in a chain are "on the same page" and socialised to the same goals, standards and practices (Ouchi 1980). This has led in some instances to moves towards convergence of the governance within value chains, where business associations of lead firms agree on the application of common standards acrosstheir suppliers (Gibbon et. al. 2010).

In their recent work on normalisation in GVCs Ponte and Sturgeon (2014) have usefully extended these issues by focusing on the role and effects of multipolar governance (Ponte and Sturgeon 2014). In ways similar to recent GPN arguments (Hughes et.al. 2010; Yeung and Coe 2015), multipolar governance refers to horizontal linkages with a range of actors and networks (including public regulators and civil society) that influence value chain structures and practices. 
This has important implications for social standards. By incorporating commercial inter-firm relations as drivers of standards with extra-firm bargaining with civic actors like trade unions and NGOs, multipolar approaches are more attentive to the dynamics of a range of actors and how they shape specific configurations of, and commitments to, social standards. The interaction between multi-polar governance and commercial dynamics can vary depending on the corporate culture of individual companies and markets targeted (Hughes 2015). Social standards influenced by civic conventions and norms surrounding what is deemed 'ethically responsible' corporate behaviour, can vary geographically and between different socio-economic groups (Ponte and Gibbon 2005; Guarin and Knorringa 2014; McEwen et. al. 2015). Hence it cannot be assumed emerging economy consumers will follow Northern trends.

Just as the literature identifies shifting imperatives in the governance of value chains from control through coordination to normalisation, so it is possible to trace parallel if more varied trajectories in the way TNC retailers have engaged with social standards. In relation to labour standards, a strategy of control over suppliers led to the introduction of company codes of labour practice in order to minimise corporate risk to NGO and media campaigns over labour abuse in the 1990s. However, this failed to avert further exposure affecting many companies (Barrientos and Dolan 2006). As coordination evolved as a strategy of horizontal governance, many supermarket TNCs joined wider business association such as the Global Social Compliance Programme (GSCP) discussed below. Coordination became more embedded through normalization, where companies engaged with wider external actors in multistakeholder initiatives. At the same time, expansion of Fairtrade marks and other forms of certification in their own-brand labelled goods also became part of wider governance strategies 
of value chain normalization by supermarkets seeking market differentiation and appeal for 'discerning' consumers (Doherty et. al. 2013; Hughes 2015). ${ }^{4}$ In some instances normalization led to convergence of social standards, for example in the UK many large supermarkets are members of the ETI and have adopted the ETI Base Code directly as their company code of labour practice generating convergence between their codes (Barrientos and Dolan 2006). Some individual supermarkets pursuing more niche markets have sought convergence in their commitments to, and application of, social standards throughout their retail and supply chains by integrating them into wider strategies of product quality, environmental and social responsibility (see below). This shift in governance (control to coordination to normalization to convergence) is increasingly being recognized across different product categories and chains, such as the recent IFC (2013) review of agro-food that charted the parallel evolution of sustainability initiatives (environmental and social) from inception through first movers to critical mass and normalisation; a process that institutionalised converging sustainability criteria across the sector.

In sum, social standards form part of a multi-polar system of retail GVC governance where normalisation has become increasingly embedded through conventions. In some places this has led to convergence of social standards across supermarkets and the linking of social with other standards in those supermarkets. However this process becomes more complex when supermarket operations extend across borders through broad networks of producers and consumers where commercial relations and civic conventions differ within and between regions in the global South. Whilst there is evidence that leading TNC and regional supermarkets

\footnotetext{
${ }^{4}$ Fairtrade evolved through independent civil society labelling initiatives (e.g. Max Havelaar and Traidcraft), and did not form part of a TNC strategy of control based on 'risk avoidance'.
} 
operating in emerging economies apply product and some process standards (Reardon et. al. 2007), there is less information about the extent to which this includes social standards.

\section{Governance of social standards in retail transcending the global North and South}

The rise of standards amongst retailers operating in the global South needs to be examined not only as part of an evolving process of multi-polar governance but also a multi-scalar and uneven process in which new and complex inter-linkages are emerging between TNC and regional supermarket procurement practices. This is important, because whereas an early driver of social standards within the global North was external to commercial value chains (consumer pressure fuelled by civil society and trade union activism), application of social standards by retailers based in emerging economies is being driven more by GVC governance pressures resulting from coordination and normalization already established in Northern markets than it is by 'responsible consumption' concerns on the part of retail customers..

To investigate this further, research was undertaken between 2010-13 involving supermarket and social standards initiatives in Europe, South African and Kenya, with follow up interviews with selected respondents in 2015. Selection of supermarket interviewees was made to obtain a spread of Northern supermarkets with operations in the global South, and Africanowned supermarkets operating across sub-Saharan Africa that were engaged in (or considering) application of social standards (labour and fairtrade) in Southern markets (including Africa). Interviews were conducted with standards, compliance, and business strategy leaders in 6 transnational supermarkets (four in UK, one US owned interviewed in UK and one in the Netherlands) and with 5 African supermarkets (4 in South Africa and one in Kenya). All 
supermarket personnel interviewed had operations in seven or more countries, either globally or within sub-Saharan Africa. One chocolate company was also interviewed in the UK for the Fairtrade example. Nine standards initiatives and civil society organisations (CSOs) were interviewed in the UK, Netherlands, France, Belgium, Switzerland, South Africa and Kenya. One operated globally, four operated in Europe only, two operated in Europe/Africa and two in Africa only. In total 33 individuals were interviewed across all organisations (some more than once). In the discussion of findings below, respondents are coded across three groups (supermarket, company, CSO). We do not name or identify individuals or their position to maintain anonymity. In brief, we found that there are differential drivers of social standards emerging across these actors. We report these below in relation to different channels for standards' convergence: (i) those led by global retailers; (ii) those led by social standards initiatives; and (iii) those involving convergence between social standards and national legislation. Following this we explore the implications for multi-polar governance.

\section{(i) Convergence of social standards led by transnational retailers}

As transnational retailers expand into new regions they tend to transfer their own product and process standards. They do so in order to differentiate themselves from traditional retailers and to avoid risk to their global brand reputation (Ponte and Gibbon 2005). The extent to which they incorporate social standards into their overseas operations varies. Where TNC supermarkets leverage their supply base to gain economies of scale by sourcing in volume across all their countries of operation, social standards driven by pressure in the global North apply de facto to the same products sold in emerging markets. One clear example of a TNC retailer driving convergence across its global sourcing and retail base is Wal-Mart. In September 2009, Walmart 
held a conference with its 1,000 top suppliers in China, laying out its minimum conditions and timetable for both social and environmental compliance among all its suppliers. Wal-Mart also centralised all its country global social compliance managers under its Bentonville HQ in the late 2000s and has since applied the same standard to all its global outlets (supermarket interviews A1 and A2, UK 2010). ${ }^{5}$ Further, during 2012 Massmart was integrated into Walmart's procedures (supermarket interview H1, South Africa 2012) and subsequently joined Walmart's ethical sourcing programme. ${ }^{6}$

Another dimension of convergence is the integration of product, social and environmental standards, such as Marks and Spencer's Plan A introduced across all its outlets in Europe, the Middle East and Asia. ${ }^{7}$ Other supermarkets are also planning similar strategies. One Dutch retailer interviewed said the number of different labels now appearing on their products is causing increasing confusion for suppliers and customers. It is now integrating different standards under its own label, so that customer confidence is based on brand trust and not weakened by a proliferation of labels (supermarket interview B1, Netherlands 2011). A CSO interviewee foresaw this as a process in which labelling would move from 'front of the packet, to back of the packet, to not on the packet' (CSO interview P1, Netherlands 2011). This would then apply to all outlets and all products sold in all the countries in which the supermarket operates. The goal is clearly to offer consumers a 'one-stop' full compliance option as a point of departure for subsequent differentiation strategies. It is also meant to address confusion around a multitude of labels and to streamline supply chain governance indicators.

\footnotetext{
${ }^{5}$ See also Sum (2012) and J.Birchell 'Walmart Sees Green in China', Financial Times 21/10/08.

${ }^{6}$ See www.massmart.co.za/sustainability/economic-impact/ accessed September 2015.

${ }^{7}$ See: www.corporate.marksandspencer.com/plan-a
} 
An example of where coordination and normalization of GVC governance are leading to a weaker form of convergence is the Global Social Compliance Programme (GSCP). This is an initiative led by TNC supermarkets to create a collaborative response to the proliferation of social and environmental standards that are seen to be strategically important but which do not add to individual company competitive advantage (supermarket interviews D1, London 2011 and B1 Netherlands 2011; CSO interview Q1, France 2012). To achieve this, GSCP has benchmarked a series of agreed-upon minimum standards that are comparable and shared among GSCP members. This benchmarking has established reference tools and processes to create commonalities among existing practices and interpretations, and an equivalence process for the different standards companies currently use. In effect, the benchmarking and equivalence process identifies areas of agreement among already existing standards for social and environmental performance to allow any single company to accept another company's standards in a supplier firm. Effectively 'sharing' such floor standards has three primary goals. First, it moves discussion away from the proliferation of new separate social standards and, instead, focuses on enhancing convergence and reducing audit duplication among many existing codes and standards across member supply chains. ${ }^{8}$ Second, by reducing the complexity and duplication of standards the benchmarking process aims to reduce transaction costs and liability associated with multiple standards. In effect, the benchmarking allows any member company to accept the standards of any other member in supplier firms, for example when Tesco might contract with a supplier using a certification from Walmart. Such benchmarked standards and audits stand-in for a company's own standards without the need for further standards or audits. And third, by 
establishing a floor of minimum common standards and practices the program protects individual company rights to raise their own standards requirements above the minimum floor should they wish to do so for purposes of enhanced competition or market positioning.

Whilst the majority of corporate members are Northern based, the South African supermarket Pick n Pay is also a member. Pick n Pay operates in nine countries in Africa (Table 1) and has a corporate code of ethics that incorporates social standards. Its membership of GSCP is partly driven by the corporate philosophy of its $\mathrm{CEO}$, who is a leading member of the Consumer Goods Forum, a world-wide retailer organisation closely associated with GSCP (supermarket interview L1, South Africa 2011). ${ }^{9}$ But Pick n Pay also targets middle-income consumers, and its corporate philosophy forms part of its market positioning. The South African supermarket Woolworth is not a member of GSCP, but is linked indirectly through close association with Marks \& Spencer $(M \& S)$ which is a member. Woolworth also targets higher income groups in South Africa and across outlets in 17 countries mainly in Africa (Table 1). Woolworth has an integrated package of product and process standards which includes a code of labour practice against which it audits its suppliers in South Africa and externally (supermarket interview K1, South Africa, 2012). ${ }^{10}$ It aims to provide a high level of product quality, with environmental and sustainability standards comparable to M\&S within Africa. Pick n Pay and Woolworth both target middle-income consumers, and account for approximately one third of supermarket market share (Pick n Pay 28\% and Woolworth 8\%) within South Africa (Hughes 2015).

\footnotetext{
${ }^{9}$ See also http://www.theconsumergoodsforum.com/pick-n-pay-head-elected-new-co-chair-ofthe-consumer-goods-forum [accessed December 2012].

${ }^{10}$ See also ISEAL 2015.
} 
Convergence is also occurring as multi-stakeholder initiatives originally established in the global North involving TNC retailers expand their presence through initiatives within the global South. For example, the UK Ethical Trading Initiative wine pilot in South Africa led to the establishment of WIETA (a coalition of local stakeholders and wine producers) and later SIZA (a parallel initiative in the fruit sector). UK retailers are also closely associated with SIZA and WIETA. SIZA is also participating in the GSCP programme as part of the equivalence process for benchmarking standards (CSO interviews U1 and V1, South Africa, 2011 and 2013). Some South African supermarkets are associated with WIETA and SIZA, and the same wine and fruit producers also sell into supermarkets in the global South as well as North. ${ }^{11}$ Hence social compliance initially led by TNC supermarkets is effectively spilling over into emerging markets, with convergence of codes.

\section{(ii) Convergence of social standards led by standards initiatives}

Many standards setting initiatives originated through civil society advocacy in the global North, but they are increasingly also focusing their attention on emerging economies (ISEAL 2015). Fairtrade provides an example of a social standard established for Northern consumers to support improved conditions for farmers and communities in the global South (Raynolds et. al. 2007). ${ }^{12}$ For a long time Fairtrade labelled products were only sold in the global North, but are

\footnotetext{
${ }^{11}$ Woolworth, Shoprite, Pick n Pay and Spar attended SIZA's launch of joining GSCP. See also Hughes et al (2015).

${ }^{12}$ Here we use 'fair trade' as a generic term covering a number of schemes that promote social sustainability for smallholder producers and workers, including Fairtrade, Utz and Rainforest Alliance. 'Fairtrade' (one word) relates solely to certified products carrying the Fairtrade International label. Fairtrade certification covers both smallholders and wage labour on large
} 
now being sold in Southern supermarkets as Fairtrade aims to expand globally (CSO interviews: R2 South Africa 2011; and R3 Kenya 2012). The sale of certified Fairtrade products has been launched in South Africa (2009), Brazil (2011), Kenya (2013), and India (2014), selling a range of Fairtrade products such as chocolate, tea, coffee, cotton and wine.

As the first emerging economy to adopt Fairtrade certification, South Africa provides an interesting example. Establishing a Fairtrade Label in South Africa initially faced several challenges. Early sales were only in niche products in middle to higher end supermarkets, while some supermarkets resisted their introduction. Boudewijn Goossens, responsible for introduction of the Fairtrade Label within South Africa highlighted the problems: "During the start-up phase we had opposition from retail and businesses. Some were concerned that Fairtrade would make their own sustainability agendas look less significant. Others didn't believe that South Africans would be interested in buying ethical products or could afford them. But we managed to get South African traders and retailers to support the initiative and we found an increasingly large group was keen to buy ethically.",13

In practice, the South African supermarkets that have emerged as the first adopters of Fairtrade products (Woolworths, Pick n Pay and Makro) primarily target middle to higher income consumers or are part of TNC companies (e.g., Makro which is part of Massmart Holdings). From a low base, Fairtrade sales in South Africa grew from ZAR 18.4m in 2010 to

plantations, but has a longer history promoting fairer terms for smallholders in traditional crops such as tea, coffee and cocoa.

${ }^{13}$ Cited in The Guardian 'South-south trade is creating a new path for Fairtrade' 28/11/14 
ZAR 294m in 2014 (Fairtrade 2014). Between 2013-4 Fairtrade sales grew by 23\% in coffee, $35 \%$ in wine, and $190 \%$ in tea (60\% of which is locally produced Rooibos tea) (Fairtrade 2014).

A boost to the Fairtrade Label in South Africa was the launch of Fairtrade certified Cadbury Dairy Milk (FTCDM) in 2011. Cadbury's motivation for converting CDM to Fairtrade was an increasing concern over the social resilience of their cocoa supply chain. The chocolate industry had been under NGO and media scrutiny over child labour in cocoa. Research commissioned by Cadbury had indicated an aging cocoa farmer profile enduring high poverty and declining productivity with many youth leaving cocoa farming (Barrientos 2015). At the same time, consumption of chocolate was expanding rapidly (approximately $8-10 \%$ per annum in Asian markets, particularly China and India), with cocoa production failing to keep up (Barrientos 2015). Concern was reinforced by a prediction by Amajaro (a leading cocoa trader) of a one million ton shortage of cocoa by 2020 on current trends (ibid). In response to rising concerns, Cadbury initiated the Cocoa Partnership in 2008, a UK GBP45 million project to support and incentivise cocoa farmers. It converted its main line, Cadbury Dairy Milk, and related products, to Fairtrade, launching in the UK in 2009. Cadbury adopted a strategy of rolling this out to its other main markets for CDM sales (including Ireland, Canada, Australia), rather than expanding FT labelling to more Cadbury products in fewer markets. South Africa was the first emerging market chosen by Cadbury, followed by Kenya initially in discussion with Fairtrade Foundation UK and subsequently Fairtrade South Africa and Kenya (company interviews M1 and M3, UK 2015). 
A key feature of Cadbury's mainstreaming strategy was that consumers did not pay extra for FTCDM bars. The price had to remain market competitive with non-Fairtrade equivalent products, with additional costs of Fairtrade labelling and social premiums being absorbed by the company or being offset through expanded sales volumes (company interviews with M1 and M3, UK 2015). ${ }^{14}$ By using the mainstream supply chain, sales went automatically into all supermarkets supplied as well as smaller retail outlets in each country, accounting for approximately 55\% of retail sales in South Africa and 20\% in Kenya (Barrientos and Visser 2012; Evers et. al. 2014). In the first year South Africans consumed 29.4 million bars of FTCDM, generating a social premium of US\$238,000 for small-scale farmers in West Africa (Moorad 2012). As a result of these two initiatives, mainstreaming CDM increased access to supermarkets and the profile of Fairtrade in South Africa and subsequently Kenya (CSO interviews R2, South Africa 2011; and R3, Kenya 2012). It helped to boost interest in Fairtrade amongst leading retailers in both countries, opening the way for expansion of other products.

Fairtrade sales in Africa provide an example of standards convergence across markets in both the global North and South where a standards initiative combined with the action of a large manufacturer with established markets in Africa. In this case, at least, the normalisation and convergence of fair trade as a social standard was a product of more than the spill-over effects of Northern consumer pressure.

\section{(iii) Convergence of social standards and national legislation}

\footnotetext{
${ }^{14}$ Other mainstream Fairtrade products introduced have also followed a similar strategy, e.g.,
} Sainsbury own-brand Fairtrade bananas (Smith 2010). 
Whilst transnational retailers have developed their own private codes of labour practice, many incorporate compliance with national legislation as part of this requirement. For example, the UK ETI Base Code requires compliance with legislation or the code, whichever provides the higher protection. ${ }^{15}$ Wal-Mart's Standards for Suppliers Manual $(2014)^{16}$ lists national legislation as its first point of compliance. Walmart states that where sourcing crosses national jurisdictions and causes confusion over different laws, adherence to the most stringent legal requirements applies. Such standards apply to products sold in all its outlets including those in Africa, Asia and Latin America, providing a global channel for convergence across national legislative environments, and between national laws and private codes.

A Dutch-based supermarket chain has adopted a more differentiated approach, developing a ladder of supplier standards depending on the end markets for their products, with national labour regulation and ILO Core Conventions as the minimum social compliance in each market (supermarket interview B1, Netherlands, 2011). A leading UK supermarket was exploring a similar differentiated approach to its markets with its strictest social code being applied in Northern outlets but with narrower minimum standards (such as no child labour) and national legislation being required in sales by its outlets in the global South (supermarket interview A2, UK, 2013). Such approaches to emerging markets are easier to implement and sustain, but -as with the case of Wal-Mart - the power of Northern TNCs and the demands they face for the standardization of operations across their complex supply chains are increasing

\footnotetext{
${ }^{15} \mathrm{http}: / / \mathrm{www}$.ethicaltrade.org/resources/key-eti-resources/eti-base-code

${ }^{16} \mathrm{http}: / / \mathrm{cdn}$.corporate.walmart.com/d1/7e/ee6f5c8942f69ad4183bc0683771/standards-forsuppliers-manual.pdf accessed September 2015.
} 
pressure to align more demanding and complex standards and requirements with the more strict national legislations.

By contrast with this 'strong' form of compliance with national legislation, a weaker form results where African owned supermarket chains sell high volume lower priced goods into middle to lower income markets. These companies rarely require compliance with a company code of labour practice, have no independent auditing mechanisms of their own, and simply assume that their suppliers comply with national labour legislation. In particular, such supermarkets have particularly weak labour inspection practices on their supplier farms, where national labour standards are also often less stringently enforced (Alford forthcoming). Supermarkets operating elsewhere in sub-Saharan Africa often source locally, and again there are questions over the level of social standards applied, although much depends on the actual practices in different local supply chains. ${ }^{17}$

In sum, social standards are increasingly entering into the governance and regulatory practices of higher end regional supermarkets chains, and are beginning to create expanded coordination and norms among their partners and competitors. The process involves normalisation and different forms of convergence across supermarket supply chains, but the process is far from uniform and has yet to have major visible impact in some regionally based supermarket chains that do not target middle-upper end consumers. Here legislation remains the main vehicle for social standards (particularly with regard to labour).

${ }^{17}$ This was verified by two separate supermarket interviews G1 and J1 South Africa, February 2012 and by interviews for related research with producers that supplied them and other South African supermarkets (Authors forthcoming). 


\section{Implications of Different Channels of Convergence}

The above channels of standards convergence in Southern markets are not straightforward. It is important to highlight limitations and complexities of the process. In relation to labour standards, even where convergence might be occurring across the upper tiers and larger producers in GVCs, there is little evidence that social standards are filtering down to lower tiers of the same supply chains, especially where small-scale producers only supply regional (not TNC) supermarkets. For example, in related research reported elsewhere (Authors forthcoming), most of the African retail chains investigated indicated they sourced some part of their weekly fresh produce from local producers or traders. They only carried out spot checks on product quality of some of the goods supplied, relying instead on local suppliers to follow national labour regulation without further verification. Convergence of social standards at upper tiers, may well go together with divergence at lower level value chain tiers where similar standards are weak or do not prevail. Currently there is little civil society pressure to ensure this level of supply chain monitoring or compliance in Africa. The result is a complex system of overlapping but distinct standards regimes and local sourcing practices.

Focusing on multi-polar governance and the normalization and convergence of social standards does, however, provide a nuanced analysis of the multi-faceted processes driving social standards in emerging market retail. Whilst surveys indicate 'consumer responsibility' awareness is growing within emerging economies (Neilson 2013; ISEAL 2015), this paper shows it is definitely not the only and probably also not the main driver of social standards in the global South. As retail value chains develop into increasingly complex overlapping networks of 
buyers and suppliers that cross the global North and South, multi-polar governance drivers can also make an important contribution. However, this process is likely to play out differently depending on the configuration of actors and alliances in a specific GPN, and the country context. Whilst our research has highlighted three channels of convergence in the context of TNC and African supermarkets, it is very possible other studies could yield different scenarios. Our findings indicate, however, that Kaplinsky and Farouk's (2010) caution from the 2000s that social and environmental standards are unlikely to apply in emerging economies may well be changing as both Northern and Southern supermarket chains and markets respond to new challenges. We echo the call of others for deeper and more comparative investigation of these issues (Guarin and Knorringa 2014; McEwen et. al. 2015).

\section{Governance of Social Standards - Concluding Remarks}

The rise of social standards within global and regional retail value chains in the global South is a complex process that both maps onto the trajectories of globalizing strategies of Northern retail chains and differs from them. The increasing complexity of production networks means that standards can have a different relationship to governance than those in industries and sectors that operate through the control of captive suppliers. In some cases, standards are implemented by transnational supermarkets in their operations in the global South in the absence of direct NGO and consumer pressure. In other case, both regional supermarket chains and their suppliers are adapting practices initiated by Northern transnational supermarkets, and suppliers are adjusting to selling into multiple types of supply chain with varying buyer requirements. In terms of governance through coordination, Northern supermarkets are playing a dominant role, but some supermarkets in the global South (particularly targeting middle to upper income consumers) are 
also adopting equivalent standards or participating in similar business alliances. In terms of normalization of governance, standard setting by supermarkets in the global South run behind those in the global North. GSCP is at an early stage in its attempt to create a global retailers' floor of standards that operate to normalize both lead firm and their supplier practices, although some Southern lead firms are participating. There are also moves in some contexts towards convergence through adoption of the same code across retailers and/or integration of product, environmental and social standards within retailers.

The concept of normalisation seeks to capture the ways in which such industrial and civil society norms and practices become established in different forms of value chain coordination. Through what Ponte and Sturgeon (2014) have characterized as multi-polar analyses of governance it is possible to unpack the actors (commercial and non-commercial) involved in both global and regional value chains, and to assess the extra-firm bargaining processes that have emerged as integral to the commercial strategies of each (Yeung and Coe 2015). Our research thus points to the existence of geographically and organizationally different drivers of social standards within emerging economies. However, it also identifies channels for convergence of social standards across retail that transcends the global North and South. In the context of multi-polar governance, the drivers can be both TNC retailers and civil society organisations (in our example Fairtrade as a standard setting initiative).

In some contexts, normalisation of social standards is occurring through recourse to public regulation, including national legislation and trade policy on product, health and safety, labour and environmental standards. This could play a greater role in multi-polar value chain 
governance in future, especially as regional supermarkets reach out further to middle to lower income consumers with less capacity to pay. Although beyond the scope of this paper, it is important to indicate that --in some countries-- state authorities themselves have become actors in the re-regulation of the development consequences of a low-wage export-oriented model of industrialization (Mayer and Pickles 2014). A key actor in this regard has been the government of China that has revised the contract labour code, enhanced commitments and powers to regulation of health and safety, and expanded industrial policies that encourage economic and social upgrading in state and private enterprises (Zhu and Pickles 2014; Lan, Pickles and Zhu 2015).

An important contribution of this paper is to highlight the role of multi-polar governance as a driver of social standards within emerging economies. The helps to elucidate another phase in the evolution of the concept of governance as a multi-polar process increasingly extended across Northern and Southern retail spheres. We have shown how the articulation of supermarket chains and supplier networks are -at the same time — creating both standards convergence and divergence across different scales and locales of the global South. These extended forms of governance are providing channels for the application of social standards within emerging economies, driven only in part by rising consumer incomes and awareness of social issues. But they are also fragile arrangements, particularly among smaller regional supermarket chains and their local supply networks, where experience and exigency maintain unregulated commodity supplies. The rise of Fairtrade sales within the global South is recent and is still only at a relatively low level, but it indicates growing consumer awareness in a world of global communications and social media. It is also being driven through the commercial dynamics of 
GVCs via spill-overs from transnational supermarkets and increasing overlap among standards packages. But the fact that the emergence of such fair trade and standards-based models continue to operate in bifurcated retail markets raises important questions about the ways in which emerging market middle-income consumers and poorer consumers might co-shape the possibilities for more sustainable social standards in supermarkets.

\section{References}

Accenture (2011) The Dynamic African Consumer Market: Exploring Growth Opportunities in Sub-Saharan Africa, Accenture. Available at www.accenture.com (accessed June 2012).

Barrientos, S. and C. Dolan, Eds. (2006). Ethical Sourcing in the Global Food System. London, Earthscan.

Barrientos, S. and M. Visser (2012). South African Horticulture Value Chains: Opportunities and Challenges For Economic And Social Upgrading. Capturing the Gains Working Paper, No. 12, University of Manchester.

Barrientos, S. (2015) 'Beyond Fairtrade: Why are chocolate companies pursuing social sustainability in cocoa sourcing?' M. Squicciarini and J. Swinnen (Eds.) The Economics of Chocolate Oxford University Press: Oxford.

Brown, K. (2015) 'Consumer politics, political consumption and fair trade' in L. Raynolds and E. Bennett (Eds) Handbook of Research on Fair Trade, Cheltenham: Edward Elgar, pp. 157-173. 
Chan, A. (ed) (2011) Walmart in China. Ithaca: Cornell University Press.

Coe N, 2004, "The internationalisation/globalisation of retailing: towards an economic geographical research agenda" Environment and Planning A 36(9) 1571 - 1594.

Coe, N. (2014) Missing Links: Logistics, governance and upgrading in a shifting global economy Review of International Political Economy, 21(1):224-256

Coe, N., Hess, M. and Dicken, P. (2008) Global Production Networks: Realising the Potential, Journal of Economic Geography, Vol. 8:271-295.

Coe, N. and N. Wrigley, Eds. (2009). The Globalization of Retailing. London, Edward Elgar.

Coe, N. and Yeung, N. (2015) Global Production Networks, Oxford: Oxford University Press.

Dawson, J. (2003), "Towards a Model of the Impacts of Retail Internationalisation" in John Dawson, Masao Mukuyama, Sand Chul Choi and Roy Larke (eds), The Internationalization of retailing in Asia Chapter 11. London: Routledge, pp. 189-209.

Deloitte (2013). Global Powers of Retail 2013: Retail Beyond. Stores January 2013, Section 2. www.deloitte.com/.../Deloitte_Global_Powers_of_Retail_2013 
Deloitte (2015) Global Powers of Retailing 2015: Embracing Innovation.

http://www2.deloitte.com/content/dam/Deloitte/global/Documents/Consumer-Business/gx-cbglobal-powers-of-retailing.pdf

Doherty, B., Davies, I. and Tranchell, S. (2013) 'Where now for fair trade?' Business History, Vol. 55(2):161-189.

Dolan C and Humphrey J (2000) Governance and Trade in Fresh Vegetables: The Impact of UK Supermarkets on the African Horticulture Industry, The Journal of Development Studies, $37: 2,147-176$.

Evers, B., M. Opondo, et al. (2014). Global and regional supermarkets: implications for producers and workers in Kenyan and Ugandan horticulture. Capturing the Gains Working Paper No. 39. University of Manchester.

Fairtrade (2014) 'Market Research: Fairtrade South Africa' available at:

http://www.fairtrade.org.za/content/page/market-research (accessed 10/1/15).

Gereffi G. (1994). Capitalism, Development and Global Commodity Chains. In Capitalism and Development. Sklair L. (ed.). Routledge: London. pp 211-231.

Gereffi, G. (2014). "Global value chains in a post-Washington consensus world." Review of International Political Economy 21(1): 9-37. 
Gereffi G, Humphrey J, Sturgeon T. (2005) The Governance of Global Value Chains. Review of International Political Economy. 12(1): 78-104.

Gibbon, P. J. Bair and S. Ponte (2008) Governing global value chains: an introduction. Economy and Society Volume 37 Number: 315338

Gibbon, P., Ponte, S. and Lazaro, E. (2010) Global Agro-Food Trade and Standards, Basingstoke: Palgrave Macmillan.

Guarin, A. and P. Knorringa (2014). "New Middle-Class Consumers in Rising Powers:

Responsible Consumption and Private Standards." Oxford Development Studies 42(2): 151-171.

Hamilton, G., M. Petrovic, and B. Senauer Eds. (2011). The Market Makers: How Retailers are Reshaping the Global Economy. Oxford, Oxford University Press.

Henderson, J., P. Dicken, M. Hess, N. Coe, H. Yeung (2002). "Global production networks and the analysis of economic development." Review of International Political Economy 9: 436-64.

Henson, S. and J. Humphrey (2010). "Understanding the Complexities of Private Standards in Global Agri-Food Chains as they Impact Developing Countries." Journal of Development Studies 46(9): 1628-1646. 
Hess, M. (2004). "'Spatial’ relationships? Towards a reconceptualization of embeddedness." Progress in Human Geography. April, vol. 28 no. 2 165-186

Hughes, A., N. Wrigley and M. Buttle (2010). Ethical Campaigning and Buyer Driven Commodity Chains: Transforming Retailers' Purchasing Practices. Consuming Space: Placing Consumption in Perspective. M. Goodman, D. Goodman and M. Redclift. Farnham, Ashgate.

Hughes, A. (2015) 'retailers, corporate ethics and fair trade' in Raynolds, L. and Bennett, E. Handbook of Research on Fair Trade, Cheltenham: Edward Elgar, pp. 298-315.

Humphrey, J. (2007). "The supermarket revolution in developing countries: tidal wave or tough competitive struggle?" Journal of Economic Geography 7(4): 433-450.

IFC (2013) Building a roadmap to sustainability in agro-commodity production, Consortium report (team leader J. Molenaar), International Finance Corporation, Washington D.C.

ISEAL (2015) Building demand for sustainable commodities: How brands and retailers are engaging domestic markets in Brazil, China and India, ISEAL Alliance, London.

Kaplinsky, R. and M. Farooki (2010). What are the implications for global value chains when the market shifts from the North to the South? World Bank Policy Research Working Paper 5205, February 2010. 
Tu Lan, John Pickles, and Shengjun Zhu. 2015. 'State Regulation, Economic Reform and Worker Rights: The Contingent Effects of China's Labour Contract Law'. Journal of Contemporary Asia, 45(2): 266-293.

Li and Fung (2013). Retail market in China September 2013. Hong Kong Fung Business Intelligence Centre.

Lucas, L. and A. Felsted (2012). Private label goods take bigger share. Financial Times. London 7 October 2012.

Mayer F.W. and J. Pickles (2014) 'Governance and Implications for Decent Work in Apparel Global Value Chains'. Toward Better Work - Understanding Labour in Apparel Global Value Chains. International Labour Organization/Capturing the Gains. Macmillan, pp. 17-39.

McEwen C, Hughes A, Bek D (2015) Theorising middle class consumption from the global South: A study of everyday ethics in South Africa's Western Cape, Geoforum, DOI http://dx.doi.org/10.1016/j.geoforum.2015.02.011.

Moorad, Z. (2012) 'Cadbury congratulated on giving cocoa farmers a fair deal', Business Day, available http://www.bdlive.co.za/business/retail/2012/11/20/cadbury-congratulated-on-givingcocoa- (Accessed 21/11/12) 
Nadvi, K. and F. Wältring (2004). Making Sense of Global Standards Local Enterprises in the Global Economy. H. Schmitz. Cheltenham, Edward Elgar.

Neilson (2013) Ethical Product Trends in South Africa, Research for the Belgian Development Agency, Available At: http://www.befair.be/sites/default/files/all-

files/brochure/Ethical\%20product\%20trends\%20in\%20South\%20Africa\%202013.pdf (Accessed January 2015).

Neilson (2014) Doing Well by Doing Good. Available at: www.nielsen.com/us/en/insights/reports/.../doing-well-by-doing-good.ht (Accessed January 2015).

O'Rourke, D. (2006) 'Multi-stakeholder regulation: Privatizing or socializing global labor standards' World Development, Vol. 34(5):899-918.

Ouchi, W. G. (1980). Markets, bureaucracies, and clans. Administrative Science Quarterly, 129141.

Ponte S, Gibbon P. (2005) Quality Standards, Conventions and the Governance of Global Value Chains. Economy and Society 35(1): 1-31.

Ponte, S. and T. Sturgeon (2014). "Explaining governance in global value chains: A modular theory-building effort." Review of International Political Economy 21(1): 195-223. 
Raynolds, L. and J. Wilkinson (2007). Fair Trade in the agriculture and food sector: analytical dimensions. Fair Trade: The challenges of transforming globalization. L. Raynolds, D. Murray and J. Wilkinson. London, Routledge: 33-48.

Reardon, T., C. Timmer, et al. (2003). "Supermarkets in Africa, Asia and Latin America." American Journal of Agricultural Economics 85(5): 1140-6.

Reardon, T., S. Henson and J. Berdegué (2007). "'Proactive Fast-Tracking' Diffusion of Supermarkets in Developing Countries: Implications for Market Institutions and Trade." Journal of Economic Geography 7(4).

Reardon, T., P. Timmer, C.P., and Minten, B. (2010). Supermarket revolution in Asia and emerging development strategies to include small farmers. Proceedings of the National Academy of Sciences of the USA, http://www.pnas.org/content/109/31/12332.full [last accessed October 29, 2014].

Reed, D., P. Utting, and A. Mukherjee-Reed Eds. (2012). Business Regulation and Non-State Actors: Whose Standards? Whose Development? London, Routledge.

Smith, S. (2010) 'For Love or Money? Fairtrade Business Models in the UK Supermarket Sector' Journal of Business Ethics, Vol 92(2):257-266. 
Sum, N.-L. (2012). Global retail accumulation strategies and Walmart's CSR regime. Business Regulation and Non-State Actors: Whose standards? Whose development? D. Reed, P. Utting and A. Mukherjee-Reed. London, Routledge.

UNCTAD (2013). World Investment Report: Global Value Chains: Investment and Trade for Development. Geneva, United Nations Publication.

Yeung, H. W. and N. Coe (2015). "Toward a Dynamic Theory of Global Production Networks." Forthcoming in Economic Geography, Vol.91(1):29-58.

Zhu, S. and J. Pickles. (2014). "Bring In, Go Up, Go West, Go Out: Upgrading, Regionalisation and Delocalisation in China's Apparel Production Networks." Journal of Contemporary Asia Volume 44, Issue 1: 36-63. DOI:10.1080/00472336.2013.801166

Table 1. Global Retailers (2013)

\begin{tabular}{|c|c|c|c|c|c|c|}
\hline $\begin{array}{l}\text { Retail Sales Rank } \\
\text { FY } 2013\end{array}$ & $\begin{array}{l}\text { Company } \\
\text { Name }\end{array}$ & $\begin{array}{l}\text { Country } \\
\text { of Origin }\end{array}$ & $\begin{array}{r}2013 \text { Retail } \\
\text { Sales } \\
\text { (US\$ million) }\end{array}$ & $\begin{array}{r}2008-13 \\
\text { Retail Sales } \\
\text { (\% Growth) }\end{array}$ & $\begin{array}{r}\% \text { Return on } \\
\text { Assets } \\
2011\end{array}$ & $\begin{array}{r}\text { \# Countr } \\
20\end{array}$ \\
\hline \multicolumn{7}{|c|}{ Top Seven Global Retailers } \\
\hline 1 & Wal-Mart Stores Inc & US & 476,294 & 3.3 & 8.5 & \\
\hline 2 & Costco Wholesale Corp & US & 105,156 & 7.7 & 5.8 & \\
\hline 3 & Carrefour SA & France & 98,688 & -3.0 & 0.8 & \\
\hline 4 & $\begin{array}{l}\text { Schwarz Undernehmens } \\
\text { Treuhand KG }\end{array}$ & Germany & 98,662 & 6.5 & na & \\
\hline 5 & Tesco Plc & UK & 98,613 & 2.9 & 5.5 & \\
\hline 6 & The Kroger Co & US & 98,375 & 5.3 & 2.5 & \\
\hline 7 & Metro AG & Germany & 86,393 & -0.91 & 2.2 & \\
\hline
\end{tabular}

Selected Emerging Economy Retailers 


\begin{tabular}{|l|l|l|r|r|r|r}
47 & Cencosud S.A. & Chile & 19,855 & 11.3 & na & \\
\hline 90 & E-MART Co.Ltd. & S. Korea & 11,164 & na & na & \\
\hline 98 & $\begin{array}{l}\text { Dairy Farm International } \\
\text { Holding Ltd. }\end{array}$ & Hong Kong & 10,357 & 9.0 & na & \\
\hline 107 & Shoprite Holdings Ltd. & S. Africa & 10,534 & 11.5 & na & \\
\hline 148 & Pick n Pay Stores Ltd. & S. Africa & 6,351 & 4.8 & na & \\
\hline 174 & Spar Group Ltd & S. Africa & 5,175 & 12.1 & na & \\
\hline 239 & Woolworth Holdings Ltd & S. Africa & 3,834 & $13.4 \mathrm{a}$ & na & \\
\hline
\end{tabular}

Sources: Deloitte (2013 and 2015). Source 2011, 2012, 2013 data: Published company data and Planet Retail, from Deloitte $(2013,2015)$. 